\title{
RESEARCH
}

Open Access

\section{The effect of endothelial progenitor cell transplantation on neointimal hyperplasia and reendothelialisation after balloon catheter injury in rat carotid arteries}

Wei Wang ${ }^{1,2,3 \dagger}$, Yingqian Zhang ${ }^{2 \dagger}$, Hui Hui ${ }^{3,4+}$, Wei Tong ${ }^{1,2,3}$, Zechen Wei ${ }^{3,4}$, Zhongxuan Li ${ }^{2}$, Suhui Zhang ${ }^{1,2,3}$, Xin Yang ${ }^{3,4}$, Jie Tian ${ }^{3,4,5^{*}}$ and Yundai Chen ${ }^{2 *}$

\begin{abstract}
Background: Reendothelialisation is the natural pathway that inhibits neointimal hyperplasia and in-stent restenosis. Circulating endothelial progenitor cells (EPCs) derived from bone marrow (BM) might contribute to endothelial repair. However, the temporal and spatial distributions of reendothelialisation and neointimal hyperplasia after EPC transplantation in injured arteries are currently unclear.
\end{abstract}

Methods: A carotid balloon injury (BI) model was established in Sprague-Dawley rats, and PKH26-labelled BMderived EPCs were transplanted after BI. The carotid arteries were harvested on the first, fourth, seventh, and 14th day post-injury and analysed via light-sheet fluorescence microscopy and pathological staining $(n=3)$. EPC and human umbilical vein endothelial cell culture supernatants were collected, and blood samples were collected before and after transplantation. The paracrine effects of VEGF, IGF-1, and TGF- $\beta 1$ in cell culture supernatants and serum were analysed by enzyme-linked immunosorbent assay $(n=4)$.

Results: Transplanted EPCs labelled with PKH26 were attached to the injured luminal surface the first day after BI. In the sham operation group, the transplanted EPCs did not adhere to the luminal surface. From the fourth day after $\mathrm{Bl}$, the mean fluorescence intensity of PKH26 decreased significantly. However, reendothelialisation and inhibition of neointimal hyperplasia were significantly promoted by transplanted EPCs. The degree of reendothelialisation of the $\mathrm{EPC}^{7 \mathrm{~d}}$ and $E P C^{14 \mathrm{~d}}$ groups was higher than that of the $\mathrm{Bl}^{7 \mathrm{~d}}$ and $\mathrm{Bl}^{14 \mathrm{~d}}$ groups, and the difference in neointimal hyperplasia was observed between the EPC ${ }^{14 d}$ and $\mathrm{BI}^{14 \mathrm{~d}}$ groups. The number of endothelial cells on the luminal surface of the $\mathrm{EPC}^{14 \mathrm{~d}}$ group was higher than that of the $\mathrm{Bl}^{14 \mathrm{~d}}$ group. The number of infiltrated macrophages in the injured artery decreased in the EPC transplanted groups.

(Continued on next page)

\footnotetext{
* Correspondence: jie.tian@ia.ac.cn; cyundai@vip.163.com

${ }^{+}$Wei Wang, Yingqian Zhang, and Hui Hui contributed equally to this work as co-first authors.

${ }^{3}$ CAS Key Laboratory of Molecular Imaging, Institute of Automation, Chinese Academy of Sciences, Beijing 100190, China

${ }^{2}$ Department of Cardiology, the Sixth Medical Centre, Chinese PLA General Hospital, Beijing 100853, China

Full list of author information is available at the end of the article
} 
(Continued from previous page)

Conclusions: Transplanted EPCs had chemotactic enrichment and attached to the injured arterial luminal surface. Although decreasing significantly after the fourth day at the site of injury after transplantation, transplanted EPCS could still promote reendothelialisation and inhibit neointimal hyperplasia. The underlying mechanism is through paracrine cytokines and not differentiation into mature endothelial cells.

Keywords: Endothelial progenitor cells, Reendothelialisation, Neointimal hyperplasia, Angioplasty, Light-sheet fluorescence microscopy

\section{Background}

Coronary artery disease (CAD) is the leading cause of disability and morbidity $[1,2]$. Percutaneous coronary intervention has revolutionised the treatment of CAD, but it injures vascular endothelial cells (VECs). The injured vascular endothelium can cause vascular inflammation, which accelerates lipid deposition and thrombosis. These changes contribute to neointimal hyperplasia and in-stent restenosis (ISR) [3, 4]. The use of drug-eluting stents (DESs) inhibits neointimal hyperplasia but also inhibits reendothelialisation. ISR occurs in approximately $10 \%$ of patients with DESs [5]. Reendothelialisation is a natural pathway that inhibits neointimal hyperplasia and ISR. It is important for promoting reendothelialisation to prevent ISR. Endothelial progenitor cells (EPCs) may contribute to endothelial repair [6, 7]. EPCs capturing biomolecules are immobilised onto metal-based biomaterial surfaces to accelerate reendothelialisation [8]. Circulating EPCs may not only accelerate reendothelialisation by paracrine signalling but also differentiate into mature VECs $[9,10]$. Alternatively, EPCs may never differentiate into mature VECs and only induce the proliferation and migration of original mature VECs nearby [11, 12]. EPCs could be divided into two main groups as follows to investigate their functions: haematopoietic and non-haematopoietic EPCs [13-16]. EPCs in the culture of mononuclear cells (MNCs) isolated from bone marrow (BM) after 7-14 days should be identified as haematopoietic EPCs. These spindle-shaped cells have pro-angiogenic paracrine actions [17-19]. EPCs in culture after 14-28 days should be identified as non-haematopoietic EPCs. These cells could replace and differentiate into mature VECs [20-22]. The early functional EPCs, a type of haematopoietic EPCs, are characterised by the expression of CD133, CD34, and vascular endothelial growth factor receptor 2 (VEGFR2) [23-26]. Although considerable efforts have been made to investigate how EPCs accelerate reendothelialisation, the underlying mechanism remains uncertain. The temporal and spatial distributions of reendothelialisation and neointimal hyperplasia of injured arteries after EPC transplantation are currently unclear.

We established a carotid balloon injury (BI) model and treated the BM-derived early EPCs. To fully evaluate temporal changes in neointimal hyperplasia and reendothelialisation after injury, the carotid arteries were harvested at different time points after transplantation. We present a three-dimensional (3D) investigation of the repair process after EPC transplantation for the purpose of locating and quantifying the extent of EPC attachment, reendothelialisation, and neointimal hyperplasia precisely. By evaluating the fluorescence intensity of PKH26-labelled EPCs at different time points after cell transplantation, we found that the attachment of EPCs to the damaged luminal surface did not persist. Transplanted EPCs were attached to the damaged luminal surface on the first day post-injury. From the fourth day, PKH26-labelled EPCs no longer appeared on the damaged surface. This indicates that EPCs do not directly differentiate into mature VECs but could still promote reendothelialisation and inhibit neointimal hyperplasia.

\section{Methods}

\section{BM-derived EPC isolation and identification}

Sprague-Dawley (SD) rats (male, 140-150 g, SPF) from the Charles River Laboratories Supplier in China (Beijing, China, SCXK2016-0006) were euthanised by cervical dislocation. The rat tibias and femurs of both sides (four long bones from the hind limbs) were rinsed repeatedly to obtain the BM. To isolate MNCs, Histopaque-1083 (Sigma-Aldrich, St. Louis, MO, USA) was used for cell suspension by density gradient centrifugation. After isolation, MNCs were seeded on a 100$\mathrm{mm}$ plate at a density of $2.5 \times 10^{6}$ cells $/ \mathrm{cm}^{2}$. These plates were coated at $37^{\circ} \mathrm{C}$ using fibronectin (R\&D Systems, Minneapolis, MN, USA) $24 \mathrm{~h}$ before seeding. Cells were cultured with EGM-2 (Lonza, Walkersville, MD, USA) containing $5 \%$ foetal bovine serum. After $24 \mathrm{~h}$, floating cells in the medium were removed. The culture medium was changed daily for the first 3 days and then every 48 h. Five days later, cell clusters were observed. Spindleshaped EPCs that appeared between the 7th and 14th days were identified as early EPCs, a type of haematopoietic EPC (Fig. 1a-c). Cells double-positive for Dil-acLDL and FITC-UEA-1 dual staining (85\%) were identified as EPCs (Fig. 1d-f). PKH26-labelled EPCs were monitored for the fluorescent signal of PKH26 (Fig. 1g- 

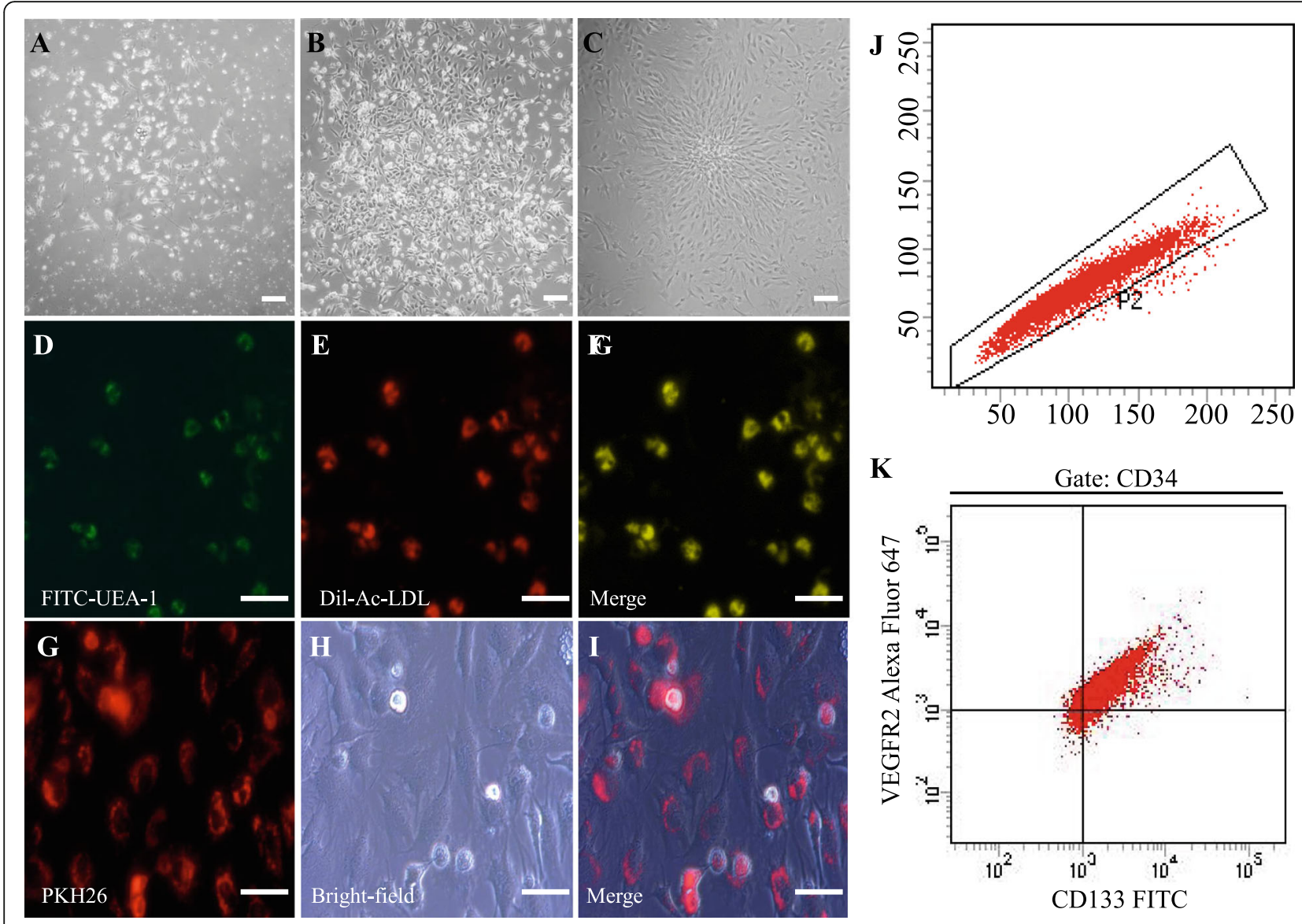

Fig. 1 Identification of bone marrow-derived EPCs. a Adherent cells formed a cluster on the fifth day of culture. $\mathbf{b}$ The cell cluster grew into a colony on the seventh day of culture. c The typical colonies, consisting of a central core of rounded cells surrounded by spindle-shaped cells, appeared at the second day post-passage. Scale bar $=100 \mu \mathrm{m}(\mathbf{a}-\mathbf{c})$. Cells positive for FITC-UEA-1 staining (d, green) and Dil-ac-LDL staining (e, red). $\mathbf{f}$ Merged images represented double-positive for the uptake of Dil-ac-LDL and binding with FITC-UEA-1. The double-positive cells accounted for $85 \%$ of the total. Confocal microscopic images (g, red), bright-field microscopic images (h), and merged images of PKH26-labelled bone marrow-derived EPCs (i). Scale bar $=50 \mu \mathrm{m}(\mathbf{d}-\mathbf{i})$. j Cells were positive for CD34 in flow cytometry. $\mathbf{k}$ Cells were positive for CD34, VEGFR2, and CD133. The triple-positive cells accounted for $75 \%$ of the total

i). Cells were triple-positive for VEGFR2, CD34, and CD133 (75\%) in flow cytometry (Fig. 1j, k). EPCs at passage 3 were obtained and used in further experiments.

Between the 7th and 14th days of culture, cells were prepared as a single cell suspension. After resuspension in fluorescence-activated cell sorting buffer $(100 \mu \mathrm{L}), 5 \times 10^{5}$ cells were incubated with rabbit anti-CD133/FITC conjugated antibody (1:100; Bioss Co., Ltd., Beijing, China, bs4770R-FITC), CD34 monoclonal antibody (QBEND/10), PE (1:10; Thermo Fisher Scientific Inc., MA, USA, MA110205), and VEGFR2 (D5B1) rabbit mAb (Alexa Fluor 647 conjugate) (1:50; Cell Signaling Technology Inc., MA, USA, 12658) for $60 \mathrm{~min}$ at $4{ }^{\circ} \mathrm{C}$ in the dark. The cells were washed twice with phosphate-buffered saline (PBS) (P3813, Sigma-Aldrich). After resuspension in fluorescenceactivated cell sorting buffer $(500 \mu \mathrm{L})$, cells were analysed by flow cytometry (BD LSRFortassa; Becton Dickinson, NJ, USA) with BD FACSDiva software (version 7.0).
During the 8 days of culture, attached EPCs were washed with PBS and subsequently stained with 1,1'dioctadecyl-3,3,3',3'-tetramethylindocarbocyanine-labelled acetylated low-density lipoprotein (Dil-ac-LDL, Maokang Biotechnogy Co., Ltd., Shanghai, China, MP6013) at a concentration of $10 \mathrm{mg} / \mathrm{L}$. After incubation at $37^{\circ} \mathrm{C}$ and $5 \% \mathrm{CO}_{2}$ for $4 \mathrm{~h}$, cells were fixed with $2 \%$ paraformaldehyde (PFA) in PBS for $10 \mathrm{~min}$. Fluorescein isothiocyanate-labelled Ulex europaeus agglutinin (FITC-UEA-1, Maokang Biotechnogy Co., Ltd., Shanghai, China, MP6308) at a concentration of $10 \mathrm{mg} / \mathrm{L}$ was added. The cells were examined under a confocal fluorescent microscope (TCS SP5 II, Leica Microsystems, Germany).

\section{Animal protocols}

All animals were housed in a 12-h light/dark cycle room at a controlled temperature $\left(23 \pm 2{ }^{\circ} \mathrm{C}\right)$ and humidity 
(50-60\%) with free access to food and water. The final sample size was determined based on the preliminary results. SD rats (weight, $250-300 \mathrm{~g}$; age, 7 to 8 weeks; male; SPF) were obtained from the Charles River Laboratories Supplier in China (Beijing, China, SCXK2016-0006). All rats were fed regular rodent chow for the first week. The rats were anesthetised with $40 \mathrm{mg} / \mathrm{kg}$ body weight pentobarbital via intraperitoneal injection and subjected to BI to the right carotid artery. Briefly, the rats were placed in the supine position and the bifurcation of the right carotid artery was exposed via a midline neck incision. A balloon angioplasty catheter was inserted through the incision in the artery. The balloon was then inflated at $2-3 \mathrm{~atm}$ and passed through the artery three times. The punched area was sealed, and the common carotid artery resumed blood flow. Rats received either $1 \times 10^{6}$ PKH26-labelled EPCs or EGM-2 medium via intravenous tail vein injection after injury. PKH26labelled EPCs injected via the tail vein after BI could be monitored (Fig. 1g-i) for the fluorescent signal of PKH26. Ibuprofen $(15 \mathrm{mg} / \mathrm{kg} /$ day $)$ was provided ad libitum as a pain killer for 3 days after the procedure. On the first, fourth, seventh, and 14th days after BI, rats were euthanised and carotid arteries were harvested (Fig. 2).
Rats were divided into the nine following groups: $\mathrm{EPC}^{1 \mathrm{~d}}$ group $(n=3), \mathrm{EPC}$ transplantation after BI and harvested on the first day; $\mathrm{BI}^{1 \mathrm{~d}}$ group $(n=3)$, medium injection after $\mathrm{BI}$ and harvested on the first day; $\mathrm{EPC}^{4 \mathrm{~d}}$ group $(n=3)$, EPC transplantation after BI and harvested on the fourth day; $\mathrm{BI}^{4 \mathrm{~d}}$ group $(n=3)$, medium injection after $\mathrm{BI}$ and harvested on the fourth day; $\mathrm{EPC}^{7 \mathrm{~d}}$ group $(n=3)$, EPC transplantation after BI and harvested on the seventh day; $\mathrm{BI}^{7 \mathrm{~d}}$ group $(n=3)$, medium injection after $\mathrm{BI}$ and harvested on the seventh day; $\mathrm{EPC}^{14 \mathrm{~d}}$ group $(n=6), \mathrm{EPC}$ transplantation after $\mathrm{BI}$ and harvested at the 14 th day; $\mathrm{BI}^{14 \mathrm{~d}}$ group $(n=6)$, medium injection after $\mathrm{BI}$ and harvested on the 14th day; and sham operation control (SC) group $(n=30)$.

\section{Perfusion and tissue preparation}

Rats were anesthetised with $40 \mathrm{mg} / \mathrm{kg}$ body weight pentobarbital via intraperitoneal injection and received $10 \mathrm{mg} / \mathrm{kg}$ body weight $0.1 \%$ Evans blue dye (SL7202, Coolaber) by intravenous tail vein injection $30 \mathrm{~min}$ before tissue harvesting. The animals were perfused transcardially with $0.01 \mathrm{M}$ PBS (P3813, Sigma-Aldrich) and $4 \%$ PFA $(158,127$, Sigma-Aldrich) in PBS. The common carotid arteries were harvested and fixed in 4\% PFA at $4{ }^{\circ} \mathrm{C}$ for at least $24 \mathrm{~h}$ before tissue clearing.

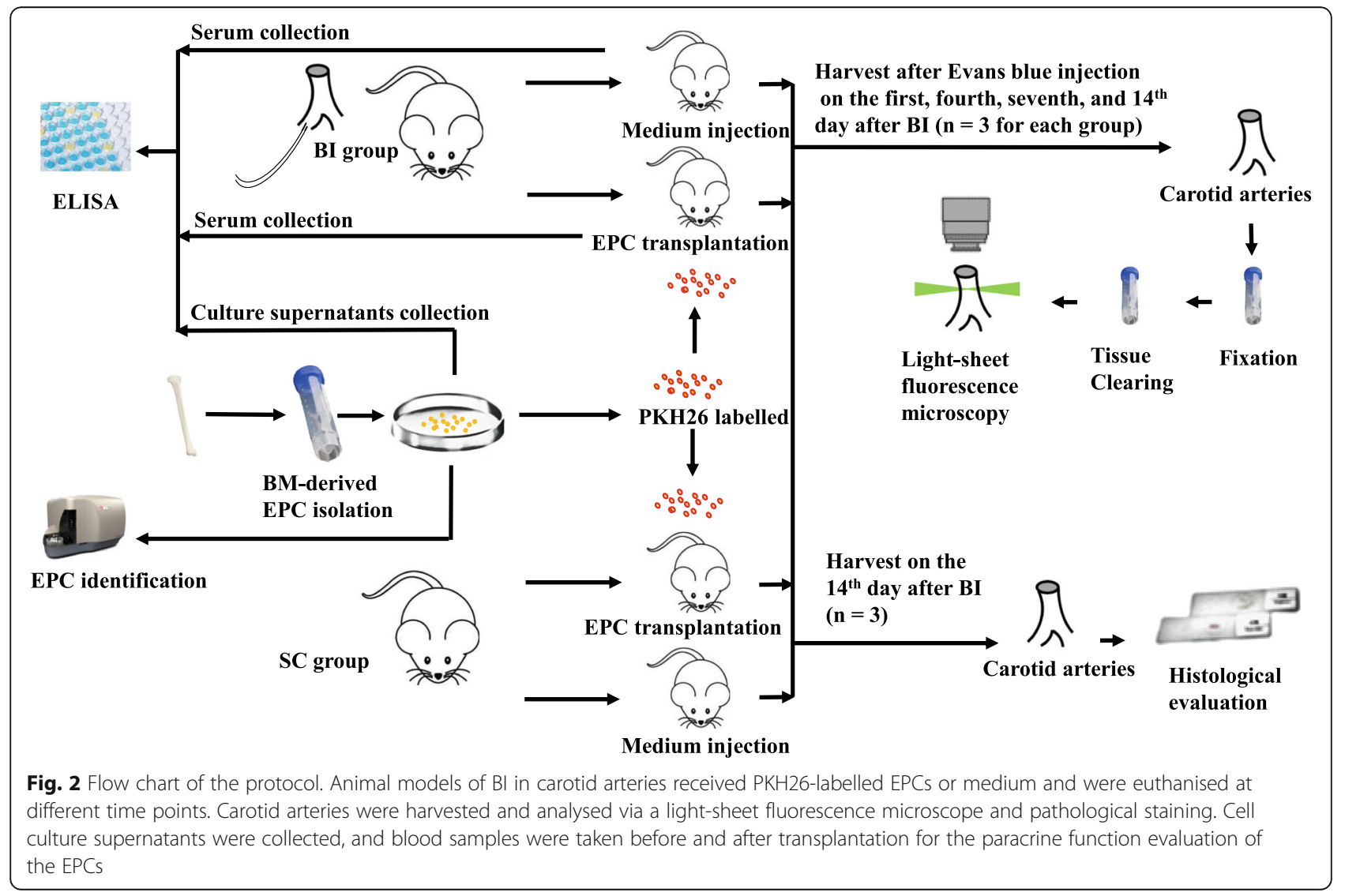




\section{Tissue clearing procedure}

The common carotid artery embedded in 1\% agar was dehydrated using the gradient dehydration method. Benzyl alcohol and benzyl benzoate (1:2) were used as the tissue clearing solutions. All steps were performed at $18^{\circ} \mathrm{C}$. Finally, the sample was placed in the dark overnight at $4{ }^{\circ} \mathrm{C}$.

\section{Light-sheet fluorescence microscopy}

All carotid arteries were collected from the origin of the common carotid artery to the bifurcation. The volumes of the neointima of different arteries were normalised by dividing by the longest carotid artery and multiplying by their lengths. Three-dimensional images of cleared carotid arteries were acquired using a light-sheet fluorescence microscope (Ultramicroscope II, LaVision Biotec, Bielefeld, Germany). We used a $\times 2.5$ objective lens $(\mathrm{Mv}$ PLAPO 2VC, Olympus) or a $\times 4$ objective lens $(\mathrm{Mv}$ PLAPO 2VC, Olympus) covered with a 6-mm working distance dipping cap. The laser source was a white light supercontinuum laser (SuperK EXTREME, NKT Photonics, Cologne, Germany). To observe cell distribution and artery morphology, the filters were set as $551 / 40 \mathrm{~nm}$ excitation and 567/50 nm emission for PKH26 and 640/ $30 \mathrm{~nm}$ excitation and $690 / 50 \mathrm{~nm}$ emission for Evans blue. The step size, scanning range, and exposure time were set to $5 \mu \mathrm{m}, 1 \mathrm{~mm}$, and $100 \mathrm{~ms}$, respectively. 3D projections of the tagged image file format images of the artery were obtained using Imaris software (Bitplane, Oxford Instruments Company).

\section{Image processing}

Images from light-sheet fluorescence microscopy (LSFM) were stored as 16-bit tag image file format. First, all images were converted to 8-bit to normalise fluorescence intensity ranging from 0 to 255 . Second, the maximum fluorescence intensity was chosen from the images of SC group as the threshold for segmenting PKH26-labelled EPCs and Evans blue-stained endothelium in experimental groups. The fluorescence intensities of all images were finally normalised from 0 to 1 range for statistical analysis. Images of haematoxylin and eosin (H\&E) and immunofluorescence were analysed using ImageJ software (version 1.52a, Wayne Rasband, National Institutes of Health, USA).

\section{Morphometric analysis}

Carotid arteries were trimmed and paraffin-embedded at the Histology and Comparative Pathology Facility. Tissue sections of $5 \mu \mathrm{m}$ thickness from three different regions of the artery were collected. Arterial sections were stained with H\&E. Endothelial cells were detected by the immunofluorescence staining of rabbit anti-CD31 antibody (Abcam, ab24590, 1:50 dilution). Inflammation was detected by immunofluorescence staining of mouse antiCD68 antibody (Abcam, ab31630, 1:200 dilution). All images of arterial sections were acquired using a confocal microscope (Leica DM3000, Germany) with exposure time set as $500 \mathrm{~ms}$.

\section{Analysis of EPC paracrine function}

The paracrine function of EPCs was evaluated by determining the levels of vascular endothelial growth factor (VEGF), transforming growth factor- $\beta 1$ (TGF- $\beta 1$ ), and insulin-like growth factor-1 (IGF-1) in cell culture supernatants and serum of $\mathrm{BI}^{1 \mathrm{~d}}$, $\mathrm{EPC}^{1 \mathrm{~d}}$, and $\mathrm{SC}$ groups using enzyme-linked immunosorbent assay (ELISA) kits. Next, $1 \times 10^{6}$ EPCs or human umbilical vein endothelial cells (HUVECs) were incubated in serum-free culture medium for $24 \mathrm{~h}$. After collection and centrifugation, the cell culture supernatants and serum were stored at $80^{\circ} \mathrm{C}$.

\section{Statistical analysis}

Continuous variables consistent with a normal distribution are presented as mean \pm SEM. Multiple group comparisons were performed using a one-way ANOVA followed by post hoc analysis using the least significant difference (LSD) $t$ test or Dunnett's T3 post hoc test using Welch's ANOVA. Statistical comparisons were performed using Student's $t$ test for experiments consisting of two independent groups only. Two-sided tests were used throughout the experiment. $P<0.05$ was considered statistically significant. Statistical analysis was performed using SPSS 19.0 (IBM, Armonk, NY, USA).

\section{Results}

The effect of EPC transplantation on neointimal hyperplasia in $\mathrm{BI}$ carotid arteries

The neointimal volume increased from $\mathrm{BI}^{1 \mathrm{~d}}, \mathrm{BI}^{4 \mathrm{~d}}, \mathrm{BI}^{7 \mathrm{~d}}$, to $\mathrm{BI}^{14 \mathrm{~d}}$. EPCs were transplanted immediately after $\mathrm{BI}$ and the volume of the neointima increased from $\mathrm{EPC}^{1 \mathrm{~d}}$, $\mathrm{EPC}^{4 \mathrm{~d}}, \mathrm{EPC}^{7 \mathrm{~d}}$, to $\mathrm{EPC}^{14 \mathrm{~d}}$. Compared with $\mathrm{BI}^{14 \mathrm{~d}}(0.105 \pm$ $\left.0.008 \mathrm{~mm}^{3}\right)$, the neointimal volume of $\mathrm{EPC}^{14 \mathrm{~d}}(0.078 \pm$ $\left.0.014 \mathrm{~mm}^{3}\right)$ was significantly smaller $(P=0.044)$. There was no significant difference between $\mathrm{EPC}^{1 \mathrm{~d}}$ and $\mathrm{BI}^{1 \mathrm{~d}}$ $\left(0.008 \pm 0.001 \mathrm{~mm}^{3}\right.$ vs. $\left.0.009 \pm 0.001 \mathrm{~mm}^{3}, \quad P=0.552\right)$, $\mathrm{EPC}^{4 \mathrm{~d}}$ and $\mathrm{BI}^{4 \mathrm{~d}}\left(0.026 \pm 0.003 \mathrm{~mm}^{3}\right.$ vs. $0.031 \pm 0.004$ $\left.\mathrm{mm}^{3}, P=0.145\right)$, and $\mathrm{EPC}^{7 \mathrm{~d}}$ and $\mathrm{BI}^{7 \mathrm{~d}}\left(0.028 \pm 0.008 \mathrm{~mm}^{3}\right.$ vs. $0.038 \pm 0.003 \mathrm{~mm}^{3}, P=0.106$ ), respectively. We also compared the neointimal area between the $\mathrm{EPC}^{14 \mathrm{~d}}$ and $\mathrm{BI}^{14 \mathrm{~d}}$ groups via $\mathrm{H} \& \mathrm{E}$ staining. The neointimal area in the $\mathrm{EPC}^{14 \mathrm{~d}}$ group was smaller than that in the $\mathrm{BI}^{14 \mathrm{~d}}$ group $\left(0.066 \pm 0.018 \mathrm{~mm}^{2}\right.$ vs. $0.137 \pm 0.008 \mathrm{~mm}^{2}, \quad P=$ 0.040) (Fig. 3). 


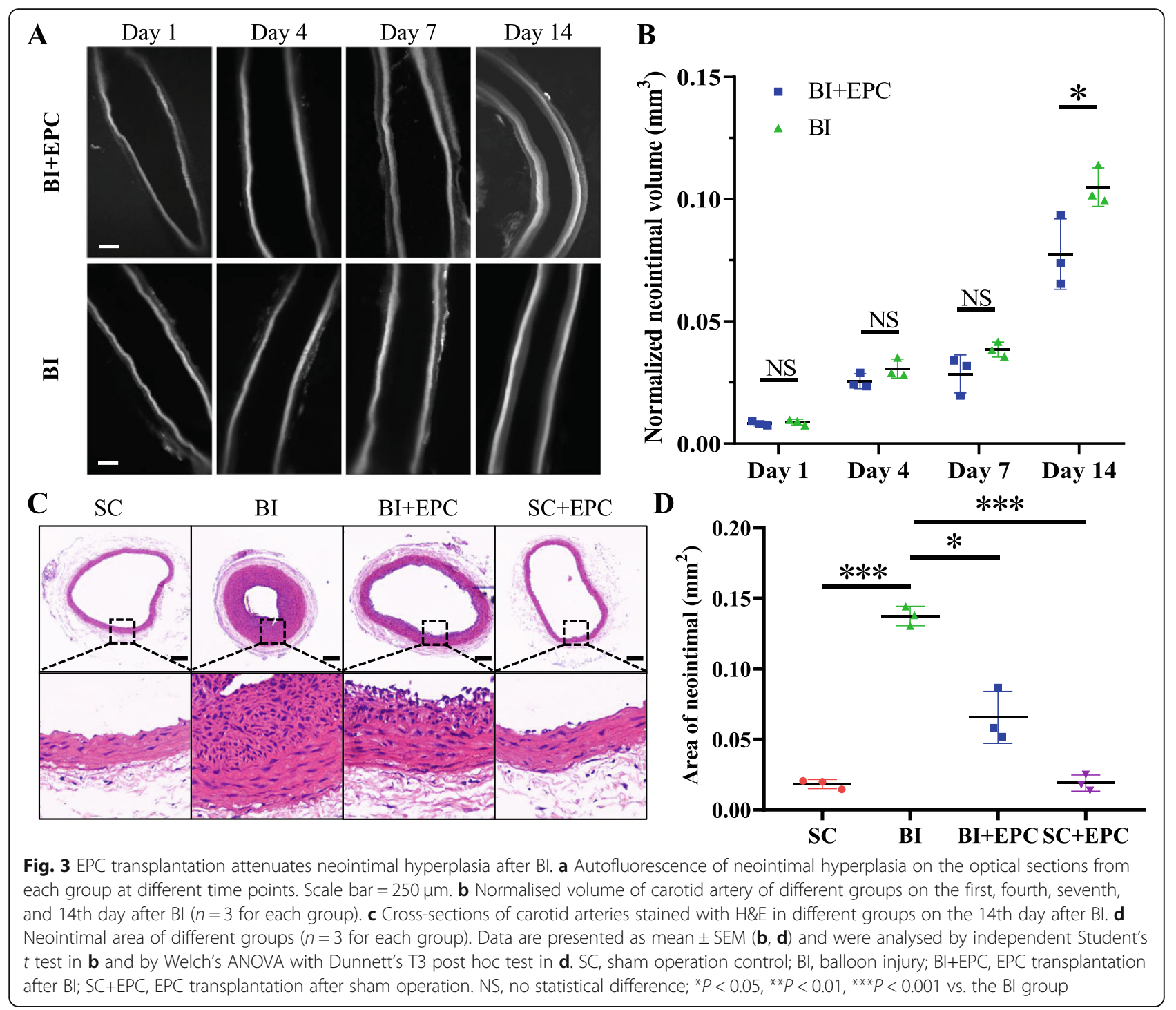

3D distribution of transplanted EPCs and the effect of EPC transplantation on reendothelialisation

We aimed to determine the reendothelialisation after BI using 3D evaluation. The distribution of transplanted EPCs changes in 3D over time, but the impairment of endothelial integrity was typically measured with cross-sections or longitudinal sections and subsequent histological analysis [27-29]. Transplanted EPCs labelled with PKH26 could be observed in the 551-nm channel under a light-sheet microscope and attached to the luminal surface of BI arteries on the first day. No PKH26-labelled cells were attached to the uninjured arteries. On the fourth day, the fluorescence intensity of PKH26 fluorescence decreased significantly on the luminal surface of the BI arteries. The normalised fluorescence intensity of PKH26 was significantly higher on $\mathrm{EPC}^{\text {1d }}$ than on $\mathrm{EPC}^{4 \mathrm{~d}} \quad(0.175 \pm 0.434$ vs. $0.095 \pm 0.041, \quad P=0.023)$,
$\operatorname{EPC}^{7 \mathrm{~d}}(0.175 \pm 0.434$ vs. $0.083 \pm 0.020, P=0.012)$, and $\mathrm{EPC}^{14 \mathrm{~d}}(0.175 \pm 0.434 \quad$ vs. $0.073 \pm 0.030, \quad P=0.007)$ groups. Evans blue could penetrate the areas where the endothelium was permeable and stain the injured surface blue. The injured endothelium labelled by Evans blue was observed in the 611-nm channel under LSFM. The normalised fluorescence intensity of Evans blue decreased from $\mathrm{BI}^{1 \mathrm{~d}}(0.411 \pm 0.088)$ to $\mathrm{BI}^{14 \mathrm{~d}}(0.344 \pm$ 0.022), and from $\mathrm{EPC}^{1 \mathrm{~d}}(0.352 \pm 0.031)$ to $\mathrm{EPC}^{14 \mathrm{~d}}(0.195 \pm$ $0.030)$ groups. The normalised fluorescence intensity of Evans blue was significantly higher on $\mathrm{BI}^{14 \mathrm{~d}}$ than on $\mathrm{EPC}^{14 \mathrm{~d}}(0.344 \pm 0.022$ vs. $0.195 \pm 0.030, P=0.002)$, and the fluorescence intensity was higher on $\mathrm{BI}^{7 \mathrm{~d}}$ than on $\mathrm{EPC}^{7 \mathrm{~d}}$ ( $0.335 \pm 0.095$ vs. $0.169 \pm 0.003, P=0.039)$. However, there was no difference between $\mathrm{BI}^{1 \mathrm{~d}}$ and $\mathrm{EPC}^{1 \mathrm{~d}}(0.411 \pm 0.088$ vs. $0.352 \pm 0.031, P=0.340$ ), or between $\mathrm{BI}^{4 \mathrm{~d}}$ and $\mathrm{EPC}^{4 \mathrm{~d}}$ $(0.378 \pm 0.029$ vs. $0.348 \pm 0.010, P=0.163)$ groups (Fig. 4 and Additional file 1). 


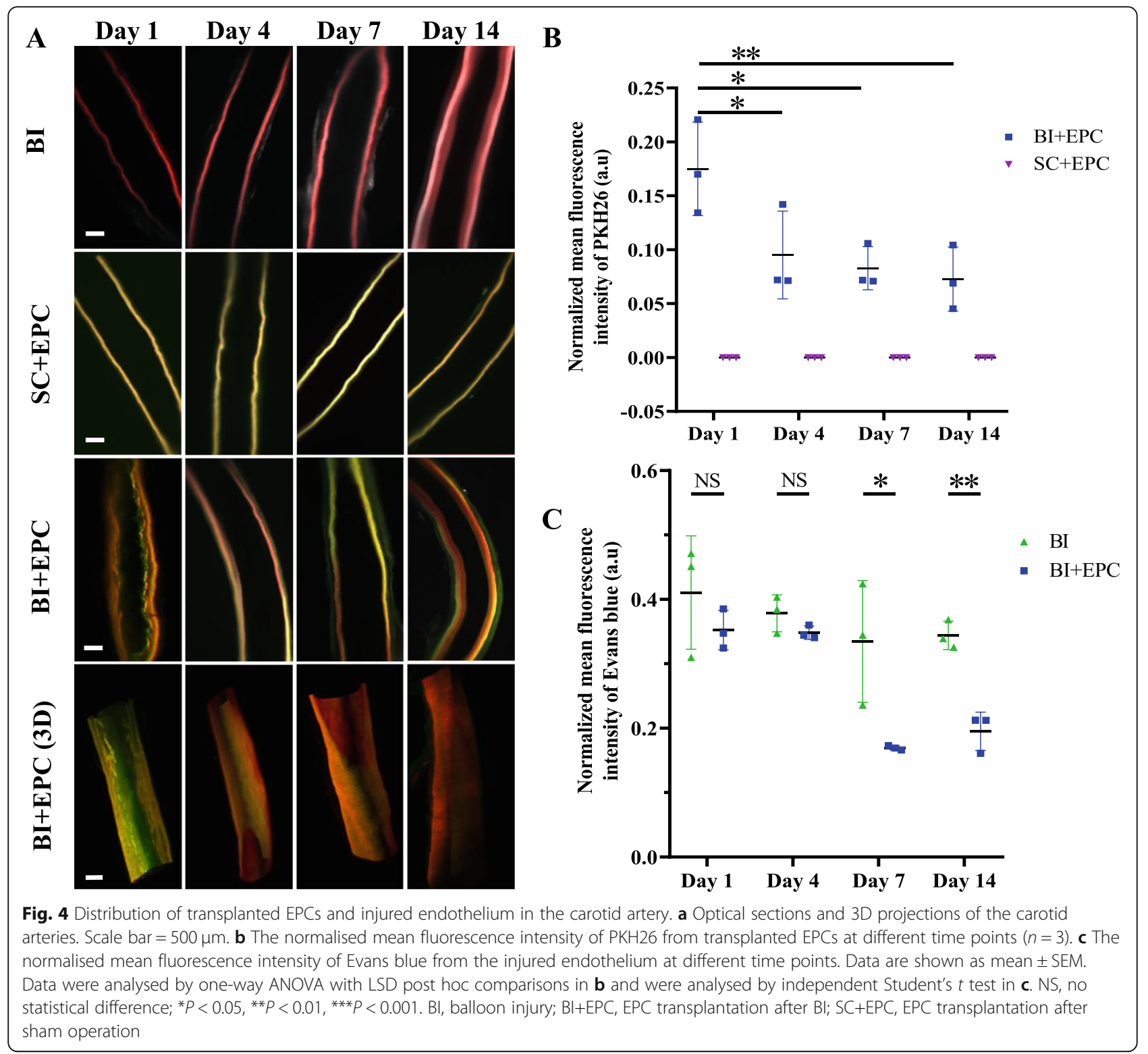

We also compared CD31 positive cells on the luminal surface between the $\mathrm{EPC}^{14 \mathrm{~d}}$ and $\mathrm{BI}^{14 \mathrm{~d}}$ groups via immunofluorescence. CD31 positive cell levels in $\mathrm{EPC}^{14 \mathrm{~d}}$ were higher than those of $\mathrm{BI}^{14 \mathrm{~d}}\left(716 \pm 131 \mathrm{cells} / \mathrm{mm}^{2}\right.$ vs. $156 \pm 10$ cells $/ \mathrm{mm}^{2}, P<0.001$ ), which is consistent with the results of the $3 \mathrm{D}$ evaluation. We evaluated the degree of macrophage infiltration in the right common carotid arteries between the $\mathrm{BI}^{14 \mathrm{~d}}$ and $\mathrm{EPC}^{14 \mathrm{~d}}$ groups via immunofluorescence. There were fewer CD68 positive cells in $\mathrm{EPC}^{14 \mathrm{~d}}$ than in $\mathrm{BI}^{14 \mathrm{~d}}\left(190 \pm 53\right.$ cells $/ \mathrm{mm}^{2}$ vs. $479 \pm 150$ cells $/ \mathrm{mm}^{2}, P=0.004$ ) (Fig. 5).

The paracrine function of the EPCs was evaluated by measuring the levels of VEGF, TGF- $\beta 1$, and IGF- 1 in cell culture supernatants and the serum of $\mathrm{BI}^{1 \mathrm{~d}}, \mathrm{EPC}^{1 \mathrm{~d}}$, and the SC groups using ELISA kits. First, $1 \times 10^{6}$ EPCs or
HUVECs were incubated in serum-free culture medium for $24 \mathrm{~h}$. In vitro, VEGF $(186.700 \pm 8.891 \mathrm{pg} / \mathrm{mL}$ vs. $9.073 \pm 0.493 \mathrm{pg} / \mathrm{mL}, \quad P<0.001), \quad$ TGF $-\beta 1 \quad(4884.625 \pm$ $986.662 \mathrm{pg} / \mathrm{mL}$ vs. $3041.499 \pm 890.529 \mathrm{pg} / \mathrm{mL}, P=0.032$ ), and IGF-1 $(5626.850 \pm 2430.089 \mathrm{pg} / \mathrm{mL}$ vs. $494.274 \pm$ $92.002 \mathrm{pg} / \mathrm{mL}, P=0.006$ ) levels of EPC culture supernatants were higher than those of HUVEC culture supernatants. The serum VEGF levels of the EPC ${ }^{1 \mathrm{~d}}$ group were higher than those in the serum of the $\mathrm{BI}^{1 \mathrm{~d}}$ group $(7.673 \pm 0.546 \mathrm{pg} / \mathrm{mL}$ vs. $2.455 \pm 0.492 \mathrm{pg} / \mathrm{mL}, P<0.001)$. The serum levels of IGF-1 in the EPC ${ }^{1 \mathrm{~d}}$ group were higher than those in the serum of $\mathrm{BI}^{1 \mathrm{ld}}(20,829.553 \pm$ $3925.356 \mathrm{pg} / \mathrm{mL}$ vs. $5953.253 \pm 2364.436 \mathrm{pg} / \mathrm{mL}, \quad P=$ 0.004). There was no difference in the levels of TGF- $\beta 1$ between $\mathrm{EPC}^{1 \mathrm{~d}}$ and $\mathrm{BI}^{1 \mathrm{~d}}(288,567.810 \pm 36,198.920 \mathrm{pg} /$ 

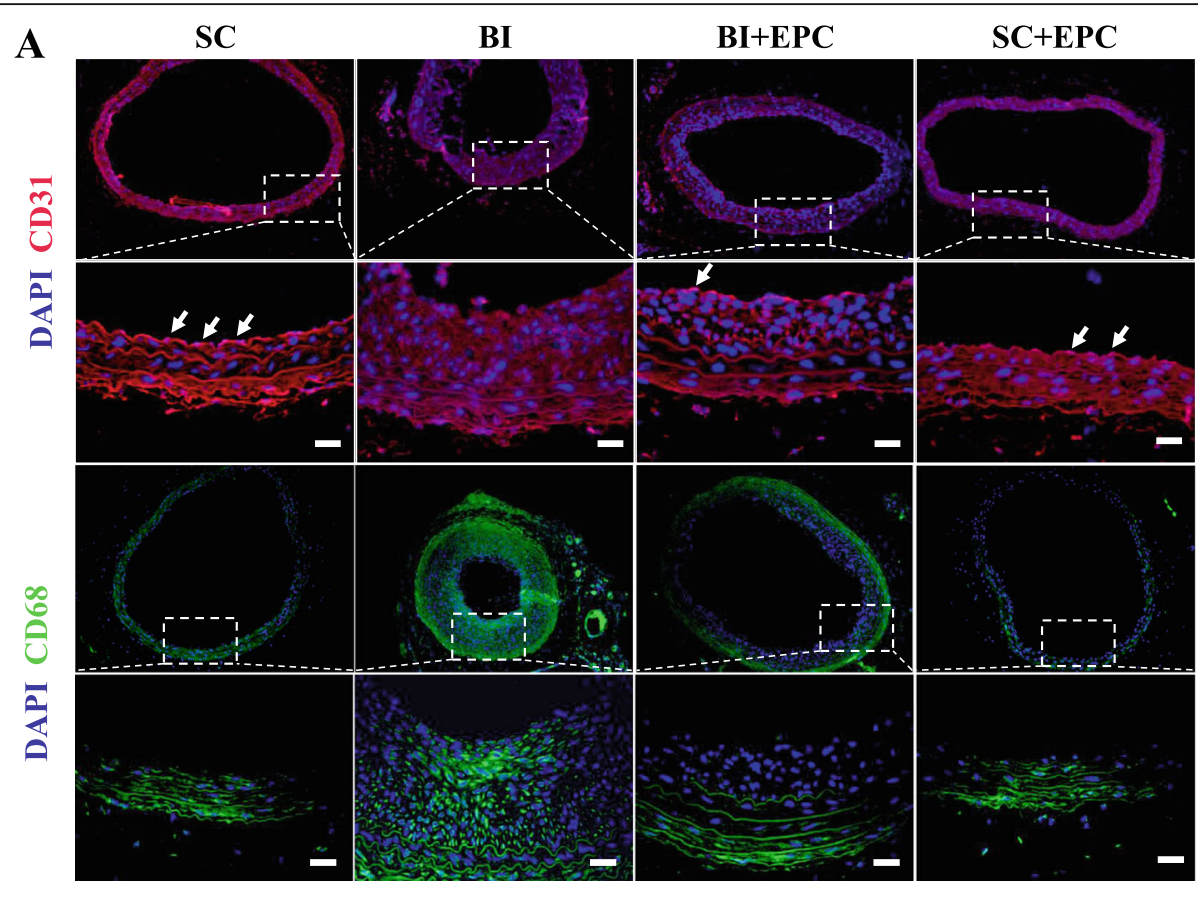

B
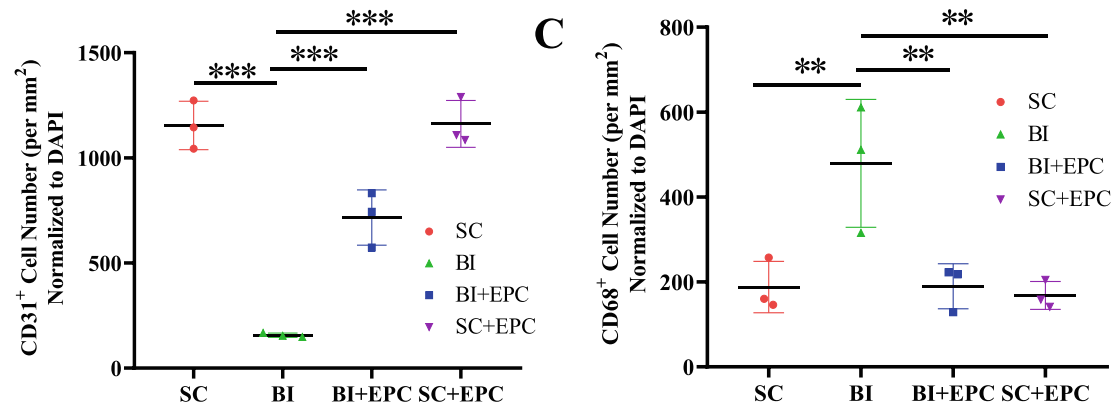

Fig. 5 Immunofluorescence staining analysis. a Immunofluorescence of CD31 and CD68 in the carotid arteries of different groups. Arrows indicate endothelial cells. Quantification of CD31 (b) and of CD68 (c) staining from images in a. Data are presented as mean \pm SEM and were analysed by one-way ANOVA with LSD post hoc comparisons, $n=3$. NS, no statistical difference; ${ }^{*} P<0.05,{ }^{* *} P<0.01$, ${ }^{* * *} P<0.001$ vs. the Bl group. SC, sham operation control; BI, balloon injury; BI+EPC, EPC transplantation after Bl; SC+EPC, EPC transplantation after sham operation

$\mathrm{mL} \quad$ vs. $\quad 250,389.093 \pm 28,614.938 \mathrm{pg} / \mathrm{mL}, \quad P=0.082)$ (Fig. 6).

\section{Discussion}

This study demonstrated that transplanted EPCs have chemotactic enrichment and can be attached to the injured luminal surface. Although the mean fluorescence intensity of PKH26 decreased significantly on the luminal surface from the fourth day after transplantation, reendothelialisation was significantly accelerated and neointimal hyperplasia was inhibited in the EPC transplanted groups compared with the medium injection groups. An in vitro study found that EPCs could secrete VEGF, TGF- $\beta 1$, and IGF- 1 . An in vivo study found that VEGF and IGF-1 levels increased significantly in the serum of $\mathrm{EPC}^{1 \mathrm{~d}}$ compared with that in the $\mathrm{BI}^{1 \mathrm{~d}}$ group. There was a trend of increasing TGF- $\beta 1$ in the serum of the $\mathrm{EPC}^{1 \mathrm{~d}}$ group. The possible mechanism by which EPCs facilitate reendothelialisation of the BI arteries is at least partially mediated by paracrine cytokines.

We established a rat carotid BI model to induce neointimal hyperplasia [30-32]. The mechanism of injury was similar to that of percutaneous transluminal coronary angioplasty. Neointimal formation and reendothelialisation are 3D processes. However, they are typically measured in two dimensions without an accurate reconstruction [33, 34]. Traditional two-dimensional analyses cannot fully evaluate the spatial distribution of neointimal hyperplasia and reendothelialisation. Selection bias as well as underestimation or overestimation will occur. For irregular geometry, the processes of neointimal hyperplasia and reendothelialisation should be evaluated in 3D. LSFM has been used to process 3D reconstruction of cardiac structures in zebrafish and mice 


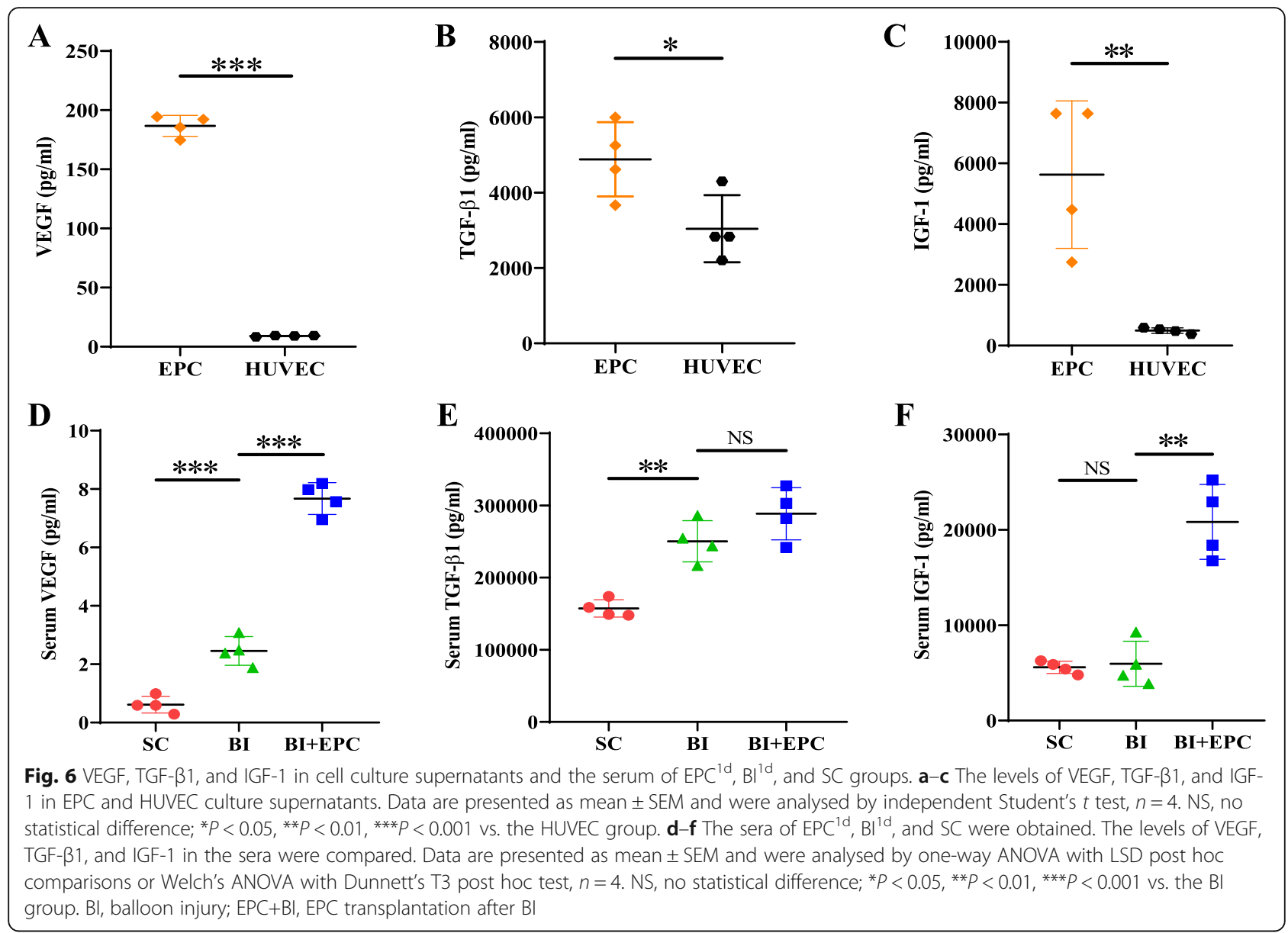

[35, 36]. In combination with tissue clearing techniques, LSFM has been used to characterise the murine brain, cochleae, and atherosclerosis plaques [37-39]. Therefore, LSFM has ability to visualise the spatial distribution of endothelium injury, neointimal hyperplasia, reendothelialisation, and transplanted EPC distribution in BI arteries.

In this study, we applied the tissue clearing method in combination with LSFM for evaluation of intact neointi$\mathrm{mal}$ in 3D. We found that the degree of neointimal hyperplasia changed with time after BI. The neointimal volume increased from $\mathrm{BI}^{1 \mathrm{~d}}, \mathrm{BI}^{4 \mathrm{~d}}, \mathrm{BI}^{7 \mathrm{~d}}$, to $\mathrm{BI}^{14 \mathrm{~d}}$. With $\mathrm{EPC}$ transplantation, neointimal volume also increased from $\mathrm{EPC}^{1 \mathrm{~d}}$, $\mathrm{EPC}^{4 \mathrm{~d}}, \mathrm{EPC}^{7 \mathrm{~d}}$, to $\mathrm{EPC}^{14 \mathrm{~d}}$. The restoration of the intact endothelium after injury is of great significance for the prevention of neointimal hyperplasia and stent thrombosis $[40,41]$. Reendothelialisation can be accelerated by EPC transplantation [42-44]. The neointimal volume of EPC ${ }^{14 \mathrm{~d}}$ was significantly smaller than that of $\mathrm{BI}^{14 \mathrm{~d}}$, while there was no significant difference between $\mathrm{EPC}^{1 \mathrm{dd}}$ and $\mathrm{BI}^{1 \mathrm{dd}}$, $\mathrm{EPC}^{4 \mathrm{~d}}$ and $\mathrm{BI}^{4 \mathrm{~d}}$, or $\mathrm{EPC}^{7 \mathrm{~d}}$ and $\mathrm{BI}^{7 \mathrm{~d}}$.

When exploring the mechanisms by which transplanted EPCs accelerate reendothelialisation, previous studies have come to different conclusions. Hagensen et al. suggested that the migration of adjacent arterial endothelial cells is the only source of reendothelialisation $[11,12]$. However, other studies have stated that transplanting EPCs not only promoted reendothelialisation through the paracrine function, but also differentiated into mature ECs $[10,45,46]$. Transplanted EPCs labelled with PKH26 were attached to the injured luminal surface on the first day after BI. For the undamaged arteries, the transplanted EPCs never adhered to the luminal surface. Our results support the idea that transplanted EPCs have chemotactic enrichment and adhere to the site of endothelial injury. The mechanism by which EPCs can migrate to the injured luminal surface has been revealed in previous studies. CXC chemokine receptor 4 positively increased CXCL12 production and promoted the chemotactic enrichment of EPCs together with CXCL12. MicroRNA-126 enriched in apoptotic VECs during endothelium injury increased the content of CXCL12 and promoted the migration of EPCs to the injured site $[47,48]$. In this study, from the fourth day after BI, the mean fluorescence intensity of PKH26 decreased significantly. PKH26-labelled cells were 
monitored for 100 days and could be positive on the newborn cell membrane with cell proliferation. PKH26 did not appear in the reendothelialisation region from the fourth day after $\mathrm{BI}$, indicating that the PKH26labelled EPCs did not differentiate into mature endothelial cells to cover the injured luminal surface. Although transplanted EPC levels decreased significantly at the site of injury on the fourth day after transplantation, reendothelialisation at the site of injury and inhibition of neointimal hyperplasia were significantly promoted. Reendothelialisation of $\mathrm{EPC}^{7 \mathrm{~d}}$ and $\mathrm{EPC}^{14 \mathrm{~d}}$ groups was significantly better than that of the $\mathrm{BI}^{7 \mathrm{~d}}$ and $\mathrm{BI}^{14 \mathrm{~d}}$ groups, and a statistical difference in neointimal hyperplasia was observed between $\mathrm{EPC}^{14 \mathrm{~d}}$ and $\mathrm{BI}^{14 \mathrm{~d}}$. The number of endothelial cells on the luminal surface of $\mathrm{EPC}^{14 \mathrm{~d}}$ was greater than that of $\mathrm{BI}^{14 \mathrm{~d}}$. Infiltrated macrophage levels at the injured site decreased after EPC transplantation on the 14th day after BI. Therefore, the underlying mechanism of reendothelialisation promoted by EPC transplantation is not differentiation into mature ECs.

Active components of EPC paracrine secretion facilitated the proliferation and migration of VECs, and these effects were associated with the expression of VEGF and IGF [49-51]. VEGF can promote reendothelialisation, inhibit neointimal hyperplasia, and play a crucial role in vascular repair [45]. Levels of cytokines, such as VEGF, TGF- $\beta 1$, and IGF-1, all increased after EPC transplantation $[52,53]$. EPCs secreted VEGF, TGF- $\beta 1$, and IGF-1 in vitro. VEGF and IGF-1 levels increased significantly in the serum of $\mathrm{EPC}^{1 \mathrm{~d}}$ compared with that in the $\mathrm{BI}^{1 \mathrm{~d}}$ group. There was a trend of increasing TGF- $\beta 1$ in the serum of the EPC ${ }^{1 \mathrm{~d}}$ group, but there was no significant difference compared with the $\mathrm{BI}^{1 \mathrm{~d}}$ group. This could be associated with the serum being collected from a systemic blood sample instead of being obtained directly from the BI lesion. Therefore, the mechanism by which EPCs can facilitate reendothelialisation of the BI arteries is more likely to be paracrine cytokines. Moreover, previous studies selected the seventh, 14th, and 28th days after injury as the time points to study reendothelialisation. The changes in EPCs and reendothelialisation in the early period after BI and EPC transplantation, especially the time before the seventh day, are seldom investigated. Our study demonstrated that EPCs chemotactically adhere to the injured site and secrete cytokines in the early period of $\mathrm{BI}$ to promote reendothelialisation.

There are limitations to the present study. First, we used only a segment of the right common carotid artery instead of the entire artery due to the size requirements of LSFM; thus, the entire common carotid artery will be analysed in a future study. Second, our methodology requires the harvesting of the carotid artery of interest and thus does not allow sequential assessments in the same animal.

\section{Conclusions}

We found that EPC transplantation attenuates neointimal hyperplasia and accelerates reendothelialisation after BI. Transplanted EPCs chemotactically adhere to the injured luminal surface and secrete cytokines in the early period. EPC transplantation promotes reendothelialisation through paracrine cytokines, such as VEGF, TGF$\beta 1$, and IGF-1, but not differentiation into mature endothelial cells.

\section{Supplementary Information}

The online version contains supplementary material available at https://doi. org/10.1186/s13287-021-02135-w.

Additional file 1: Movie S1. 3D reconstruction of carotid arteries.

\section{Abbreviations}

CAD: Coronary artery disease; VEC: Vascular endothelial cell; DES: Drugeluting stent; EPC: Endothelial progenitor cell; MNC: Mononuclear cell; BM: Bone marrow; VEGFR: Vascular endothelial growth factor receptor; BI: Balloon injury; 3D: Three-dimensional; SC: Sham operation control; SD: Sprague-Dawley; PBS: Phosphate-buffered saline; Dil-ac-LDL: 1,1'Dioctadecyl-3,3,3',3'-tetramethylindocarbocyanine-labelled acetylated lowdensity lipoprotein; PFA: Paraformaldehyde; FITC-UEA-1: Fluorescein isothiocyanate-labelled Ulex europaeus agglutinin; H\&E: Haematoxylin and eosin; VEGF: Vascular endothelial growth factor; TGF: Transforming growth factor; IGF-1: Insulin-like growth factor; ELISA: Enzyme-linked immunosorbent assay; HUVEC: Human umbilical vein endothelial cell; LSD: Least significant difference; LSFM: Light-sheet fluorescence microscopy

\section{Acknowledgements}

The authors would like to acknowledge the instrumental and technical support of multimodal biomedical imaging experimental platform, Institute of Automation, Chinese Academy of Sciences.

\section{Authors' contributions}

WW, $Y Z$, and $H H$ designed and performed the experiments, analysed and interpreted the data, prepared the figures, and wrote the manuscript. $W T, Z L$, $S Z$, and $X Y$ performed the experiments. ZW analysed and interpreted the data. JT and YC conceptualised the studies, designed the experiments, and evaluated all data. All authors read and approved the final manuscript.

\section{Funding}

This work was supported in part by the National Key Research and Development Program of China under Grant 2017YFA0700401,

2016YFC0103803, and 2017YFA0205200; the National Natural Science Foundation of China (Grant Nos. 81800221, 81671731, 81827808, 81671851, 81870178, 81527805, 81971680, 81970443); the Capital Clinical Feature Research Project (Grant Nos. Z171100001017158); the CAS Strategic Priority Research Program under Grant XDB32030200 and the CAS Scientific Instrument R\&D Program under Grant YJKYYQ20170075; and the Youth Innovation Promotion Association under Grant 2018167, of the Chinese Academy of Sciences.

\section{Availability of data and materials}

All data generated or analysed during this study are included in this published article and its supplementary information files.

\section{Ethics approval and consent to participate}

All animal studies and procedures were performed according to a protocol approved by the Chinese PLA General Hospital Animal Care and Use Committee in accordance with the National Institutes of Health Guideline on the Care and Use of Laboratory Animals. 


\section{Consent for publication}

Not applicable.

\section{Competing interests}

The authors declare that they have no competing interests.

\section{Author details}

'Medical School of Chinese PLA, Chinese PLA General Hospital, Beijing 100853, China. ${ }^{2}$ Department of Cardiology, the Sixth Medical Centre, Chinese PLA General Hospital, Beijing 100853, China. ${ }^{3}$ CAS Key Laboratory of Molecular Imaging, Institute of Automation, Chinese Academy of Sciences, Beijing 100190, China. ${ }^{4}$ University of Chinese Academy of Sciences, Beijing, China. ${ }^{5}$ Beijing Advanced Innovation Center for Big Data-Based Precision Medicine, School of Medicine, Beihang University, Beijing 100083, China.

\section{Received: 13 October 2020 Accepted: 1 January 2021}

\section{Published online: 03 February 2021}

\section{References}

1. Timmis A, Townsend N, Gale C, Grobbee R, Maniadakis N, Flather M, et al. European Society of Cardiology: cardiovascular disease statistics 2017. Eur Heart J. 2018:39(7):508-79.

2. Benjamin EJ, Muntner P, Alonso A, Bittencourt MS, Callaway CW, Carson AP, et al. Heart disease and stroke statistics-2019 update: a report from the American Heart Association. Circulation. 2019;139(10):e56-e528.

3. Dangas GD, Claessen BE, Caixeta A, Sanidas EA, Mintz GS, Mehran R. In-stent restenosis in the drug-eluting stent era. J Am Coll Cardiol. 2010;56(23):1897907.

4. $\quad$ Ding $H$, Zhang T, Du Y, Liu B, Liu Y, Wang F. HUCMNCs protect vascular endothelium and prevent ISR after endovascular interventional therapy for vascular diseases in T2DM rabbits. Mol Cell Biochem. 2017:433(1-2):161-7.

5. Kokkinidis DG, Waldo SW, Armstrong EJ. Treatment of coronary artery instent restenosis. Expert Rev Cardiovasc Ther. 2017;15(3):191-202.

6. Griese DP, Ehsan A, Melo LG, Kong D, Zhang L, Mann MJ, et al. Isolation and transplantation of autologous circulating endothelial cells into denuded vessels and prosthetic grafts: implications for cell-based vascular therapy. Circulation. 2003:108(21):2710-5.

7. Hristov M, Weber C. Endothelial progenitor cells in vascular repair and remodeling. Pharmacol Res. 2008;58(2):148-51.

8. Cui Y, Zhou F, Wei L, Song Q, Tan J, Zeng Z, et al. In situ endothelialization promoted by SEMA4D and CXCL12 for titanium-based biomaterials. Semin Thromb Hemost. 2018:44(1):70-80.

9. Rana D, Kumar A, Sharma S. Endothelial progenitor cells as molecular targets in vascular senescence and repair. Curr Stem Cell Res Ther. 2018; 13(6):438-46.

10. Yin $Y$, Liu H, Wang F, Li L, Deng M, Huang $L$, et al. Transplantation of cryopreserved human umbilical cord blood-derived endothelial progenito cells induces recovery of carotid artery injury in nude rats. Stem Cell Res Ther. 2015;6(1):37.

11. Hagensen MK, Shim J, Thim T, Falk E, Bentzon JF. Circulating endothelial progenitor cells do not contribute to plaque endothelium in murine atherosclerosis. Circulation. 2010;121(7):898-905.

12. Hagensen MK, Raarup MK, Mortensen MB, Thim T, Nyengaard JR, Falk E, et al. Circulating endothelial progenitor cells do not contribute to regeneration of endothelium after murine arterial injury. Cardiovasc Res. 2012;93(2):223-31.

13. Medina RJ, Barber CL, Sabatier F, Dignat-George F, Melero-Martin JM, Khosrotehrani K, et al. Endothelial progenitors: a consensus statement on nomenclature. Stem Cells Transl Med. 2017:6(5):1316-20.

14. Asahara T, Kawamoto A, Masuda H. Concise review: circulating endothelial progenitor cells for vascular medicine. Stem Cells. 2011;29(11):1650-5.

15. Perrotta F, Perna A, Komici K, Nigro E, Mollica M, D'Agnano V, et al. The state of art of regenerative therapy in cardiovascular ischemic disease: biology, signaling pathways, and epigenetics of endothelial progenitor cells. Cells. 2020;9(8):1886

16. Chopra H, Hung MK, Kwong DL, Zhang CF, Pow EHN. Insights into endothelial progenitor cells: origin, classification, potentials, and prospects. Stem Cells Int. 2018;2018:9847015.

17. Kanzler I, Tuchscheerer N, Steffens G, Simsekyilmaz S, Konschalla S, Kroh A, et al. Differential roles of angiogenic chemokines in endothelial progenitor cell-induced angiogenesis. Basic Res Cardiol. 2013;108(1):310.
18. Richards WO, Prutzman KB, O'Hea MF, Audia JP, Alvarez DF. Bariatric surgery improves the circulating numbers and biological activity of late outgrowth endothelial progenitor cells. Surg Obes Relat Dis. 2014;10(5):906-13.

19. Minami Y, Nakajima T, Ikutomi M, Morita T, Komuro I, Sata M, et al. Angiogenic potential of early and late outgrowth endothelial progenitor cells is dependent on the time of emergence. Int J Cardiol. 2015;186:305-14.

20. Hur J, Yoon CH, Kim HS, Choi JH, Kang HJ, Hwang KK, et al. Characterization of two types of endothelial progenitor cells and their different contributions to neovasculogenesis. Arterioscler Thromb Vasc Biol. 2004;24(2):288-93.

21. Ingram DA, Mead LE, Tanaka H, Meade V, Fenoglio A, Mortell K, et al. Identification of a novel hierarchy of endothelial progenitor cells using human peripheral and umbilical cord blood. Blood. 2004;104(9):2752-60.

22. Yoder MC, Mead LE, Prater D, Krier TR, Mroueh KN, Li F, et al. Redefining endothelial progenitor cells via clonal analysis and hematopoietic stem/ progenitor cell principals. Blood. 2007:109(5):1801-9.

23. Hristov M, Weber C. Endothelial progenitor cells: characterization, pathophysiology, and possible clinical relevance. J Cell Mol Med. 2004;8(4): 498-508.

24. Hristov M, Erl W, Weber PC. Endothelial progenitor cells: isolation and characterization. Trends Cardiovasc Med. 2003;13(5):201-6.

25. Golab-Janowska M, Paczkowska E, Machalinski B, Kotlega D, Meller A, Safranow K, et al. Elevated inflammatory parameter levels negatively impact populations of circulating stem cells (CD133+), early endothelial progenitor cells (CD133+NEGFR2+), and fibroblast growth factor in stroke patients. Curr Neurovasc Res. 2019;16(1):19-26.

26. Golab-Janowska M, Paczkowska E, Machalinski B, Meller A, Kotlega D, Safranow $K$, et al. Statins therapy is associated with increased populations of early endothelial progenitor (CD133+NEGFR2+) and endothelial (CD34-/ CD133- NEGFR2+) cells in patients with acute ischemic stroke. Curr Neurovasc Res. 2018;15(2):120-8.

27. Tang F, Liu M, Zeng O, Tan W, Long J, Liu S, et al. Gefitinib-coated balloon inhibits the excessive hyperplasia of intima after vascular injuries through PI3KJAKT pathway. Technol Health Care. 2019;27(S1):331-43.

28. Gong Z, Han Y, Wu L, Xia T, Ren H, Yang D, et al. Translocator protein 18 $\mathrm{kDa}$ ligand alleviates neointimal hyperplasia in the diabetic rat artery injury model via activating PKG. Life Sci. 2019;221:72-82.

29. Fan $Y$, Chen $Y$, Zhang J, Yang F, Hu Y, Zhang $L$, et al. Protective role of RNA helicase DEAD-box protein 5 in smooth muscle cell proliferation and vascular remodeling. Circ Res. 2019;124(10):e84-e100.

30. Gao Y, Gao CY, Zhu P, Xu SF, Luo YM, Deng J, et al. Ginsenoside Re inhibits vascular neointimal hyperplasia in balloon-injured carotid arteries through activating the eNOS/NO/cGMP pathway in rats. Biomed Pharmacother. 2018:106:1091-7.

31. Qiu L, Xu C, Chen J, Li Q, Jiang H. Downregulation of the transcriptional coactivator PCAF inhibits the proliferation and migration of vascular smooth muscle cells and attenuates NF-KB-mediated inflammatory responses. Biochem Biophys Res Commun. 2019:513(1):41-8.

32. Fan $T$, He J, Yin Y, Wen K, Kang Y, Zhao H, et al. Dioscin inhibits intimal hyperplasia in rat carotid artery balloon injury model through inhibition of the MAPK-FoxM1 pathway. Eur J Pharmacol. 2019;854:213-23.

33. Zhang J, Chen J, Yang J, Xu C, Hu Q, Wu H, et al. Suv39h1 downregulation inhibits neointimal hyperplasia after vascular injury. Atherosclerosis. 2019; 288:76-84.

34. Duan Y, Zhang Y, Qu C, Yu W, Tana, Shen C. CKLF1 aggravates neointimal hyperplasia by inhibiting apoptosis of vascular smooth muscle cells through PI3KJAKT/NF-KB signaling. Biomed Pharmacother. 2019;117:108986.

35. Ding Y, Ma J, Langenbacher AD, Baek Kl, Lee J, Chang CC, et al. Multiscale light-sheet for rapid imaging of cardiopulmonary system. JCI Insight. 2018; 3(16):e121396.

36. Merz SF, Korste S, Bornemann L, Michel L, Stock P, Squire A, et al. Contemporaneous 3D characterization of acute and chronic myocardial I/R injury and response. Nat Commun. 2019;10(1):2312.

37. Chung K, Wallace J, Kim SY, Kalyanasundaram S, Andalman AS, Davidson TJ, et al. Structural and molecular interrogation of intact biological systems. Nature. 2013:497(7449):332-7.

38. Becher T, Riascos-Bernal DF, Kramer DJ, Almonte VM, Chi J, Tong T, et al. Three-dimensional imaging provides detailed atherosclerotic plaque morphology and reveals angiogenesis after carotid artery ligation. Circ Res. 2020;126(5):619-32.

39. Dai M, Yang Y, Omelchenko I, Nuttall AL, Kachelmeier A, Xiu R, et al. Bone marrow cell recruitment mediated by inducible nitric oxide synthase/ 
stromal cell-derived factor-1alpha signaling repairs the acoustically damaged cochlear blood-labyrinth barrier. Am J Pathol. 2010;177(6):308999.

40. Zhang YQ, Tian F, Zhou Y, Chen YD, Li B, Ma Q, et al. Nicorandil attenuates carotid intimal hyperplasia after balloon catheter injury in diabetic rats. Cardiovasc Diabetol. 2016;15:62.

41. Ma X, Hibbert B, Dhaliwal B, Seibert T, Chen YX, Zhao X, et al. Delayed reendothelialization with rapamycin-coated stents is rescued by the addition of a glycogen synthase kinase-3beta inhibitor. Cardiovasc Res. 2010;86(2): 338-45.

42. Sheu JJ, Hsiao HY, Chung SY, Chua S, Chen KH, Sung PH, et al. Endothelial progenitor cells, rosuvastatin and valsartan have a comparable effect on repair of balloon-denudated carotid artery injury. Am J Transl Res. 2019; 11(3):1282-98

43. Hu H, Wang B, Jiang C, Li R, Zhao J. Endothelial progenitor cell-derived exosomes facilitate vascular endothelial cell repair through shuttling miR21-5p to modulate Thrombospondin-1 expression. Clin Sci (Lond). 2019; 133(14):1629-44

44. Iso Y, Usui S, Toyoda M, Spees JL, Umezawa A, Suzuki H. Bone marrowderived mesenchymal stem cells inhibit vascular smooth muscle cell proliferation and neointimal hyperplasia after arterial injury in rats. Biochem Biophys Rep. 2018;16:79-87.

45. Li L, Liu H, Xu C, Deng M, Song M, Yu X, et al. VEGF promotes endothelial progenitor cell differentiation and vascular repair through connexin 43. Stem Cell Res Ther. 2017;8(1):237.

46. Ke X, Zou J, Hu Q, Wang X, Hu C, Yang R, et al. Hydrogen sulfidepreconditioning of human endothelial progenitor cells transplantation improves re-endothelialization in nude mice with carotid artery injury. Cell Physiol Biochem. 2017;43(1):308-19.

47. Zernecke A, Bidzhekov K, Noels H, Shagdarsuren E, Gan L, Denecke B, et al. Delivery of microRNA-126 by apoptotic bodies induces CXCL12-dependent vascular protection. Sci Signal. 2009;2(100):ra81.

48. Pei CZ, Liu B, Li YT, Fang L, Zhang Y, Li YG, et al. MicroRNA-126 protects against vascular injury by promoting homing and maintaining stemness of late outgrowth endothelial progenitor cells. Stem Cell Res Ther. 2020;11(1): 28.

49. Zhang X, Lu A, Li Z, Sun J, Dai D, Qian L. Exosomes secreted by endothelial progenitor cells improve the bioactivity of pulmonary microvascular endothelial cells exposed to hyperoxia in vitro. Ann Transl Med. 2019;7(12): 254.

50. Demetz G, Oostendorp RAJ, Boxberg AM, Sitz W, Farrell E, Steppich B, et al. Overexpression of insulin-like growth factor-2 in expanded endothelial progenitor cells improves left ventricular function in experimental myocardial infarction. J Vasc Res. 2017;54(6):321-8.

51. Sen S, Merchan J, Dean J, li M, Gavin M, Silver M, et al. Autologous transplantation of endothelial progenitor cells genetically modified by adeno-associated viral vector delivering insulin-like growth factor-1 gene after myocardial infarction. Hum Gene Ther. 2010;21(10):1327-34.

52. He XY, Chen ZZ, Cai YQ, Xu G, Shang JH, Kou SB, et al. Expression of cytokines in rat brain with focal cerebral ischemia after grafting with bone marrow stromal cells and endothelial progenitor cells. Cytotherapy. 2011; 13(1):46-53.

53. Kong Z, Hong Y, Zhu J, Cheng X, Liu Y. Endothelial progenitor cells improve functional recovery in focal cerebral ischemia of rat by promoting angiogenesis via VEGF. J Clin Neurosci. 2018;55:116-21.

\section{Publisher's Note}

Springer Nature remains neutral with regard to jurisdictional claims in published maps and institutional affiliations.

Ready to submit your research? Choose BMC and benefit from:

- fast, convenient online submission

- thorough peer review by experienced researchers in your field

- rapid publication on acceptance

- support for research data, including large and complex data types

- gold Open Access which fosters wider collaboration and increased citations

- maximum visibility for your research: over $100 \mathrm{M}$ website views per year

At $\mathrm{BMC}$, research is always in progress.

Learn more biomedcentral.com/submissions 